\begin{tabular}{l|l}
\hline Notaice & e-ISSN: 2655-9404 \\
Vol. 01 No. 1, Juni 2018 & DOI: $10.20473 /$ ntr.vli1.9094 \\
\hline
\end{tabular}

Article history: Submitted 1 May 2018; Accepted 15 May 2018; Available online 1 June 2018.

\title{
Perbandingan Pengaturan Asas Monogami Antara Negara Civil Law (Indonesia) dan Common Law (Malaysia)
}

\author{
Avisena Aulia Anita \\ avisena.aulia.anita-2016@fh.unair.ac.id \\ Universitas Airlangga
}

\begin{abstract}
Polygamy is still a debate, especially in relation to the principal of relative monogamy that prevailed in Indonesian Marriage Law, in which the opportunity to be able to do polygamy. This opens the legal loopholes of uncontrolled polygamy practices. consequently the danger to women if polygamy is not done with care. The emphasis on the principle of monogamy is a condition that allows for the first time to do polygamy. In the case of permission, replace it to destroy the large household and the victim on the woman's side. Of polygamy now with polygamy during the time of the different Prophet Muhammad. Required role in using the rules in practice polygamy in Indonesia in order for law for women more secure. Unlike Malaysia as a country with Common Law system, which considers polygamy as a criminal act. The difference is in the imposition of more stringent terms, reasons and procedures. Although the legal system between Malaysia and Indonesia is different but tightening related to requirements, reasons and procedures may apply in Indonesia as an effort to legal protection for women.
\end{abstract}

Keyword: Polygamy; Monogamy; Protection; Women.

\begin{abstract}
Abstrak
Poligami dewasa ini masih menjadi perdebatan, terutama terkait dengan keberadaan asas monogami relative yang berlaku di Hukum Perkawinan Indonesia, dimana membuka peluang untuk dapat melakukan poligami. Hal ini membuka celah hukum praktik poligami yang tidak terkontrol. akibatnya berdampak pada kaum wanita jika poligami tidak dilakukan dengan hati hati. Penekanan terhadap asas monogami relatif terdapat pada pemberian izin istri pertama untuk melakukan poligami. Dalam hal izin saja,berpotensi untuk merusak hubungan rumah tangga sangatlah besar dan yang menjadi korbannya tentu pada pihak wanita. Tentu poligami sekarang dengan poligami pada masa Rosulullah SAW berbeda. Diperlukan peran negara dalam memperketat aturan dalam praktik poligami di Indonesia agar perlindungan hukum terhadap wanita lebih terjamin. Berbeda dengan negara Malaysia sebagai Negara dengan sistem Common Law, yang menganggap poligami sebagai sebuah tindakan kriminal. Perbedaannya terletak pada pembebanan pada syarat, alasan dan prosedur yang lebih ketat. Walaupun sistem hukum antara malaysia dengan Indonesia berbeda namun pengetatan terkait dengan syarat, alasan dan prosodur diharapkan dapat juga berlaku di Indonesia untuk memberikan perlidungan hukum terhadap wanita.
\end{abstract}

Kata Kunci: Poligami; Monogami; Perlindungan; Wanita.

\section{Pendahuluan}

Secara polemis, poligami mulaisering di perdebatkan sejak tahun 1911 yaitu ketika kartini, seorang figure wanita Indonesia yang menulis penolakannya tentang bentuk perkawinan poligami dalam sebuah surat yang diterbitkan beberapa tahun setelah kematiannya. Surat tersebut dikutip oleh Mufidah CH. Sebagai berikut : 
"Tolonglah kami memerantas siasat mementingkan dari kaum laki-laki yang tidak mengenal segan itu; iblis, yang ratusan tahun mendera menginjakinjak perempuan sedemikian rupa sehingga karena akan biasa dianiaya itu perempuan tidak memandangnya lagi sebagai ketidak adilan, melainkan dengan rasa menyerah dan tawakal menerimanya sebagai hak yang wajar laki-laki, sebagai pusaka penderitaan setiap perempuan".." saya putus asa, dengan rasa pedih perih saya punter-puntir tangan saya menjadi satu. Sebagai manusia seorang diri saja yang merasa tidak mampu melawan kejahatan berukuran raksasa itu dan yang aduh, alangkah kejamnya, dilindungi oleh ajaran islam dan dihidupi oleh keboodohan wanita kurbannya".

Selanjutnya upaya memperketat diperbolehkannya poligami akhirnya dirumuskan dalam Undang-Undang No 1 Tahun 1974 Tentang Perkawinan, akan tetapi undangundang ini juga menunjukkan banyak pro kontra. Sehingga praktik poligami dalam perkembangannya masih banyak dan dilakukan secara tidak resmi (istri / dibawah tangan). Praktik tersebut masih banyak terjadi sampai sekarang. ${ }^{2}$ Beberapa karya terkait penjelasan diatas salah satunya jurnal milik Syeikh Al Hadi juga mengenai pembaharuan islam. Dalam jurnal tersebut mencatat lima poin dalam kerangka gerakan untuk memajukan wanita, yaitu pengakuan hak dan status wanita ditengah masyarakat, memberi aturan posisi sosial wanita memberi perlindungan, mengatur dan mengontrol praktik poligami dan menciptakan kesadaran diri kaum wanita. Ini menunjukkan bahwa gerakan untuk kemajuan wanita serta perlindungan hukum bagi wanita menjadi sesuatu yang tidak terpisahkan dari pembaharuan pemikiran islam. ${ }^{3}$

Saat terjadi perdebatan seputar praktik poligami. Hamka juga merespon dengan sangat hati-hati dan menurutnya yang terbaik adalah monogami, poligami memang lebih aman dibanding mengawini wanita yatim dengan tujuan mengambil hartanya, itu pun dengan syarat yang sangat ketat. Sayangnya, informasi seperti ini kurang begitu sampai atau kurang diperhatikan oleh masyarakat grassroot sehingga tidak heran jika penafsiran tersebut belum diterima secara signifikan. Selain itu mayoritas

\footnotetext{
${ }^{1}$ Kartini, Surat-Surat Kepada Ny. Abendanon Mandiri \& Saminya (Djambatan 1989).[10]; Mufidah CH, Psikologi Keluarga Islam Berwawasan Gender.[221].

${ }^{2}$ Moh Anas Kholish dan In'amul Mushofa Warkum Sumitro, Konfigurasi Fiqih Poligini Kontemporer (Kritik Terhadap Paham Ortodoksi Perkawinan Poligini Di Indonesia) (UB Press 2009).[83].

${ }^{3}$ Ilvi Nur Diana, 'Wacana \& Gerakan Perempuan Islam Di Indonesia' E-Jurnal UIN Malang.[23].
} 
masyarakat islam Indonesia yang hidup dalam suasana tradisional diberbagai daerah masih didominasi kaum muslim tradisional yang masih merujuk kepada karyakarya klasik. Tidak heran jika implementasi ketentuan yang memperketat poligami dalam undang-undang perkawinan maupun KHI tidak berjalan secara maksimal. Respon mayoritas masyarakat terhadap dua aturan tersebut juga tidak menujukkan hasil yang menggembirakan.

Data perkara Peradilan Agama tingkat pertama se-Indonesia yang diputus tahun 2007 sejumlah 200.795 perkara, 896 perkara diantaranya tentang masalah izin poligami dengan presentase 0,446 \% (www.badilag.net). Sampai hari ini beberapa literatur di Indonesia masih menganut corak tradisional dan banyak yang masih mendukung poligami. Beberapa alasan yang mendasari hal tersebut salah satunya adalah ketimpangan jumlah kuantitas pria yang jauh lebih sedikit dari pada wanita. Padahal data BPS (Badan Pusat Statistik) ${ }^{4}$ dari sensus penduduk 2010 menunjukkan bahwa penduduk pria Indonesia justru berjumlah 119.630.913 jiwa dan wanita sebanyak 118.010.413 jiwa. Seks rasion adalah 101, berarti terdapat 101 pria untuk setiap 100 wanita. Dari data ini alasan ketimpangan kuantitas para pendukung poligami adalah paradox besar yang tidak berdasar atas data dan fakta yang sesungguhnya sehingga alasan tersebut sangat mengesankan bentuk apologi an sich.

\section{Hukum Perkawinan (Indonesia)}

Oleh karena itu mengimplementasikan produk fiqih tradisional di zaman ini juga sangat "problematik". Hal ini karena fiqih tradisional secara teoritik berlandaskan pada prinsipnya menyatunya agama dan Negara. Anehnya tidak sedikit masyarakat muslim yang mengabaikan faktor ini dan memaksakan diri menerapkan fiqih tradisional ke dalam struktur Negara modern termasuk Indonesia. Upaya ini tentu sangat sulit dilakukan tanpa melakukan rekonstruksi internal hukum islam terlebih dahulu. Rekonstruksi tersebut setidaknya karena harus mengena terhadap dua titik singgung : pertama, etika universal harus menjiwai hukum Negara karena

${ }^{4}$ Diakses pada http://sp2010.bps.go.id/7 Desember 2012, lihat juga presentasi penduduk menurut provinsi dan jenis kelamin, tahun 2009-2011. sumber: Susenas 2009-2011. 
dalam konteks ini semua ajaran agama akan bertemu. Kedua, mengedepankan Civic Reason atau Public Reason dalam wacana hukum islam kontemporer. ${ }^{5}$ Jika ditarik dalam konteks poligami, maka dapat dipastikan bahwa pembatasan poligami merupakan satu bentuk rekonstruksi internal hukum islam dengan melakukan dinamisme terhadap tuntutan masyarakat modern tanpa mengabaikan nilai-nilai islam yang universal.

Dalam kondisi normal,poligami sudah tidak sesuai dengan nilai-nilai egalitarianism universal yang berlaku di masyarakat. Dengan demikian dapat dipastikan bias tafsir klasik mengenai poligami menjadi faktor yang melatar belakangi praktik poligami dimasyarakat muslim yang seringkali disalah artikan atau disalah gunakan. Oleh karena itu sosialisasi terhadap prinsip monogami dalam perkawinan islam di Indonesia harus tetap digalakan. Di Indonesia masalah poligami diatur dalam beberapa peraturan perundangundangan yakni berupa undang-undang No 1 Tahun 1974 Tentang Perkawinan, Peraturan Pemerintah No 9 Tahun 1975 Tentang Pelaksanaan Undang-Undang Perkawinan, Inpres No 1 Tahun 1991 Tentang KHI (Kompilasi Hukum Islam). Pada dasarnya pengaturan terkait dengan poligami dalam undang-undang perkawinan dan KHI secara normatif sudah cukup baik, walaupun ada beberapa jenis poin yang perlu dibenahi. ${ }^{6}$

Meminimalisasi terhadap potensi praktik poligami yang sewenang-wenang secara eksplisit terlihat dalam bentuk penambahan syarat dalam poligami dan pemberian otoritas perizinan poligami kepada penadilan agama. Undang-undang perkawinan misalkan menganut asas monogami terbuka pada pasal 3 ayat 1 ketentuan ini mirip dengan pasal 27 BW. Poligami tidak diperbolehkan tanpa izin terlebih dahulu sebab otoritas pemberi izin poligami adalah pengadilan, dsb. Dalam kondisi poligami saat ini sangat berpotensi merusak hubungan rumah

\footnotetext{
${ }^{5}$ Hazairi, Tinjauan Mengenai UU Perkawinan, UU No 1 Tahun 1974 (Tinta Mas 2006).[13]; Hilman Hadikusuma, Hukum Perkawinan Indonesia Menurut Perundangan, Hukum Adat, Hukum Agama (Mandar Maju 2007).[37-38].

${ }^{6}$ Muhyar Fanani.XXVI.
} 
tangga. Bahkan jika seorang suami hendak mengutarakan maksud kepada istri untuk meminta persetujuan poligami hal ini tentu berpotensi besar menimbulkan kecemburuan karena dirinya telah diduakan. Itulah sebabnya kenapa penentuan syarat kondisi istri dalam undang-undang perkawinan menjadi penting.

Artinya poligami seharusnya hanya benar-benar bila dilakukan dalam kondisi yang sangat mendesak sebagi solusi dari rumah tangga dalam sebuah masyarakat yang tidak dapat menjalankan fungsi unit keluarga secara maksimal, itupun juga harus dengan pertimbangan dari berbagai hal. Jika tidak maka tidak diperbolehkan. Disinilah perlunya peran pemerintah untuk mengatur ketentuan poligini. Sebaliknya perlu disadarkan jika poligami justru menimbulkan efek efek buruk seperti diterlantarkannya istri-istri dan anak-anak yang sangat melanggar hak asasi,maka pemerintah memerlukan membuat undang-undang dan mengatur poligami se-optimal mungkin. Al Athar dalam bukunya Ta'adud Az Zaujat mencatat empat dampak negative poligami.Pertama,poligami dapat menimbulkan kecemburuan diantara para istri. Kedua, poligami dapat menimbulkan rasa kekhawatiran istri jika suami tidak bisa bersikap bijaksana dan adil. Ketiga, anak-anak yang dilahirkan dari ibu yang berlainan sangat rawan untuk terjadinya perkelahian, permusuhan, dan saling cemburu. Keempat, poligami dapat menyebabkan kekacauan dalam bidang ekonomi. ${ }^{7}$

Di Indonesia prinsip monogami sudah sangat tepat diterapkan. Akan tetapi masih sangat perlu peran Law Enforcementyang lebih serius dari pemerintah mengingat banyaknya praktik poligami tanpa izin pengadilan dan tidak sesuai dengan KHI dan undang-undang perkawinan. Tidak ada larangan mutlak terhadap poligami di Indonesia. Namun, jika dibandingkan dengan Negara-negara mayoritas muslim lainnya dan Asia Tenggara, Indonesia termasuk Negara pertengahan, tidak seperi Saudi dan Qatar yang mempermudah praktik poligami ataupun Negara Tunisia, Turki, Kamboja, Singapura, Myanmar dan Papua yang secara eksplisit melarang poligami dan menganggapnya sebagai tindakan pidana.

Sehingga jelas terlihat bahwa praktek dilapangannya terkait prosedur

${ }^{7}$ Khoirudin Nasution, Riba \& Poligami : Sebuah Studi Atas Pemikiran Muhammad Abduh (Pustaka Pelajar 1996).[100]. 
berpoligami disimpangi oleh pelaksana aturan tersebut (masyarakat Indonesia). Ini terlihat dari beberapa pasal yang bisa kita analisa, mengenai kelebihan dan kekurangan pada pasal tersebut, berikut ketentuannya :

1. Pasal 4 (ketentuan syarat alternatif pelaksanaan poligami) :bahwa pihak pengadilan bisa memberikan izin kepada suami untuk berpoligami dengan memenuhi syarat seperti yang tercantum pada pasal. Salah satunya istri mendapatkan cacat badan atau penyakit yang tidak bisa disembuhkan. Dalam hal ini terlihat jelas bahwa hak sebagai seorang wanita kurang di perhatikan dari segi perlindungan hukumnya. Jika dikaitkan dengan makna dan tujuan perkawinan serta janji dalam perkawinan bahwa "sebagai suami istri membentuk keluarga yang bahagia dan kekal" mengartikan bahwa seorang suami dalam keadaan apapun baik susah, senang, sehat ataupun sakit, tetap harus bisa membangun dan membentuk keluarga yang sehat dan bahagia serta mempertahankan rumah tangga untuk hidup bersama selamanya. Meskipun dalam hal ini bisa saja dikemudian hari terjadi hal yang tidak di inginkan dari pihak istri mengalami cacat badan (baik bawaan / permanen) padapraktiknya banyak disimpangi dengan adanya poligami bahkan perceraian. Lalu jika hal tersebut bisa saja terjadi pada pihak pria (suami). bisakah pihak istri melakukan hal yang sama terhadap suami. Hal ini jelas terjadi kesenjangan antara hak pria dan wanita. Sehingga pada pasal ini terdapat permaknaan pasal maupun pengaturan norma yang ditakutkan akan menguntungkan salah satu pihak.

2. Syarat alternatif lainnya, seperti pihak istri tidak dapat memberi dan melahirkan keturunan, menimbulkan kerancuan dimana disebutkan hanya pihak istri saja yang menjadi alasan untuk bisa terjadinya poligami (bisa dikatakan istri mengalami "mandul" tidak bisa memberi keturunan) bahkan terkesan menyudutkan pihak wanita (istri), hal yang kemudian dipertanyakan jika kemungkinan tersebut juga bisa terjadi pada pihak pria (suami) yang mengalami kemandulan. Dapat dicermati bahwa ketika UU Perkawinan ini hanya dari sisi wanita rasanya menjadi tidak adil sebab harus dilihat bahwa pihak suami juga berperan dalam memiliki keturunan. Akibatnya hal ini juga bisa disimpangi 
bahwa pihak suami bisa menganggap itu sebagai alasan berpoligami, meskipun belum dapat dibuktikan siapa yang tidak bisa memberikan keturunan. Namun, pasal ini tidak menjelaskan eksplisit terkait perlu adanya pembuktian bahwa istri tidak bisa memiliki keturunan baik pemeriksaan kesehatan, kesuburan dan pembuktian ini pun juga harus diterapkan pada suami. Kemudian bisa jadi pihak suami menolak melakukan pembuktian. Padahal justru ini sangat penting bagi hakim nantinya untuk menentukan dalam pengambilan keputusan untuk perkara poligami. Sehingga perlu adanya pasal pembuktian.

3. Pasal 5 (syarat kumulatif) adanya persetujuan dari istri / istri-istri. Pasal ini juga banyak disimpangi karena dianggap persyaratannya terlalu menyulitkan, bahwa tidak dijelaskan secara eksplisit yang dimaksud persetujuan apakah tertulis atau lisan. Sebenarnya hal ini juga dapat disimpulkan bahwa ketika istri memberikan persetujuan kepada suami untuk berpoligami dengan menandatangani perjanjian bahwa istri sepakat untuk dipoligami, secara tidak langsung pihak wanita mengetahui dan sadar atas konsekuensinya bahwa telah terjadi pelepasan hak oleh wanita atas dirinya, sehingga disinilah masalah perlindungan hukum dan kepastian hukum bagi wanita.

4. Selain itu syarat berikutnya, "suami dapat menjamin perlakuan secara adil kepada istri/istri-istrinya", meskipun dinilai perlakuan adil itu bagi setiap orang relative dan tidak sama. Dalam hal ini termasuk pula terkait memberi nafkah, bisakah kemudian pihak suami menjamin untuk seterusnya memberi nafkah sebab ditakutkan dikemudian hari tidak bisa menepati janji, karena pada prakteknya hanya beberapa bulan setelah melakukan poligami biasanya meninggalkan kewajiban untuk menafkahi, sehingga pada pasal ini pun juga tidak menerangkan secara eksplisit meskipun pada Peraturan Pemerintah No 9 Tahun 1975 telah dijabarkan bahwa perlu memenuhi persyaratan yaitu memiliki surat keterangan mengenai PPh (pajak penghasilan), serta surat keterangan mengenai penghasilan suami yang ditanda-tangani oleh bendahara tempat kerja serta surat keterangan lainnya bila diperlukan. Juga perlu dilampirkan surat pernyataan atau janji suami yang dibuat dalam bentuk yang telah ditetapkan 
pengadilan. Agar jelas jaminan agar dapat berlaku adil itu seperti apa.

Jika diamati dari beberapa pasal diatas, bahwa masih adanya celah untuk disimpangi, baik karena adanya multitafsir dalam beberapa pasal diatas, maupun karena adanya syarat alternative maupun kumulatif, yang mana pelaksanaan syarat alternative bisa salah satu dilakukan apabila memang masuk dalam unsur syarat tersebut sedangkan syarat kumulatif harus terpenuhi semuanya baru bisa dilaksanakan. Hal inilah yang kemudian menjadi kerancuan dalam pelaksanaannya.

Beberapa pendapat ulama mengenai poligami salah satunya adalah Haifah A. Jawad, kelompok ini cenderung melarang poligami, karena keadilan sebagai syarat poligami adalah sesuatu yang tidak dapat dicapai oleh setiap laki-laki (seperti halnya firman allah SWT dalam surah An-nisa (4) : 129) ${ }^{8}$ dan salah satu pendukung pendapat ini adalah Muhammad Abduh..$^{9}$ Menurut Abduh, poligami dibenarkan Syar'I dalam keadaan darurat seperti perang di zaman Rasulullah karena banyak laki-laki yang terbunuh sehingga wanita kehilangan suami mereka, namun kedaaan darurat tersebut dengan syarat tidak menimbulkan kerusakan dan kezaliman. Menurutnya, poligami dianggap baik hanya sebatas konteks umat islam generasi awal, atau pada masa islam tradisional. Namun untuk saat ini pada masa islam modern, poligami menjadi bencana dan hanya menimbulkan konflik, kebencian dan permusuhan antara istri dan anak-anak.

Disamping itu sebab bolehnya poligami untuk konteks modern telah hilang dan berlaku adil pun tidak mungkin tercapai. Poligami dalam pandangan Abduh, dengan demikian adalah haram Qath'i. ${ }^{10}$ pendapat serupa juga dikemukakan Qasim Amin, Aminah Wadud, Nasr Hamid Abu Zayd, Maulana Umar Ahmad Ustmani, Maulana Muhammad Ali, Asghar Ali Engeener, dan Rifaat Hasan. ${ }^{11}$ Meskipun pendapat ulama-ulama diatas tidak sepenuhnya sama, tetapi essensinya adalah

\footnotetext{
${ }^{8}$ M. Yunan Yusuf, 'Karakteristik Tafsir Al-Qur'an Di Indonesia Abad Keduapuluh', Ulumul Qur'an III Vol 4 (1992).[51].

${ }^{9}$ Haifah A. Jawaad, Otentisitas Hak-Hak Perempuan Dalam Islam.[150].

${ }^{10}$ ibid.[151].

${ }^{11}$ Khoiruddin Nasution, Status Wanita Di Asia Tenggara (INIS 2002); Amiur Nuruddin \& Azhari Akmal Tarigan, Hukum Perdata Islam Di Indonesia : Studi Kritis Perkembangan Hukum Islam Dari Fikih, UU No 1 Tahun 1974 (Prenada Media Group 2006).[177].
} 
mereka menolak poligami sebagai institusi sah bahkan anjuran dalam islam. Di Indonesia perkawinan dalam undang-undang perkawinan berdasarkan atas asas monogami, namun tetap dibuka peluang untuk bisa berpoligami dengan alasan dan syarat tertentu. ${ }^{12}$ Pasal 3 undang-undang perkawinan menyebutkan : (1) pada asasnya dalam suatu perkawinan seorang pria hanya boleh mempunyai seorang istri. Seorang perempuan hanya boleh mempunyai seorang suami. (2) pengadilan dapat memberi izin kepada sorang suami untuk beristri lebih dari seorang apabila dikehendaki oleh pihak-pihak yang bersangkutan.

Izin poligami hanya dapat diberikan bila memenuhi sekurang-kurangnya salah satu syarat alternatif dan tiga syarat kumulatif. ${ }^{13}$ Syarat alternatif meliputi yaitu : (a) istri tidak dapat menjalankan kewajibannya sebagai istri, (b) istri mendapat cacat badan atau penyakit yang tidak dapat disembuhkan, (c) istri tidak dapat melahirkan keturunan. Syarat kumulatif : (a) ada persetujuan tertulis dari istri-istri, (b) adanya kepastian bahwa suami mampu menjamin keperluan hidup istri dan anak-anak mereka, (c) ada jaminan bahwa suami akan berlaku adil terhadap istri-istri dan anakanaknya. Demikian lembaga poligami diatur dalam undang-undang perkawinan dan Peraturan Pemerintah No 9 tahun 1975 dan bila terjadi pelanggaran terhadap aturan diatas maka dihukum dengan hukuman denda setinggi-tingginya.

Bagi pegawai pencatatan melanggar ketentuan yang telah diatur, dihukum dengan hukuman kurungan selama-lamanya 3 bulan atau denda. Selain itu ada pula Surat Edaran Mahkamah Agung (SEMA) tanggal 20 Agustus 1975 yang menentukan bahwa mulai 1 Oktober 1975 pasal 279 KUHPidana diberlakukan terhadap pria islam yang melangsungkan perkawinan poligami tanpa izin pengadilan, yaitu diancam dengan hukuman 5 tahun penjara. Sebelumnya poligami juga diatur dalam BW (Buergerlijk Wetboek) dalam pasal 27 BW disebutkan bahwa“dalam waktu yang sama seorang laki-laki hanya dibolehkan memiliki satu orang perempuan sebagai istrinya,

\footnotetext{
${ }^{12}$ A.Bakri Rahman \& Ahmad Sukardja, Hukum Perkawinan Menurut Islam, Undang-Undang Perkawinan \& Hukum Perdata (Hidakarya Agung 1981).[9].

${ }^{13}$ Khoiruddin Nasution.Op.Cit.[108]; Khoiruddin Nasution, 'Polygami In Indonesia Islamic Family Law' (2008) jilid 16 B jurnal syariah.
} 
seorang perepuan hanya memiliki satu orang laki-laki sebagai suaminya".

Prinsip monogami yang berlaku pada BW adalah menerapkan monogami absolute sehingga prinsip inipun juga dikuatkan dengan sanksi dalam KUHPidana yang menyatakan bahwa perkawinan (setelah satu kali)menghalangi sahnya perkawinan berikutnya. Selain ketentuan diatas, diatur pula ketentuan poligami bagi PNS (Pegawai Negeri Sipil) yang dicantumkan dalam Peraturan Pemerintah No 10 Tahun 1983 dan diubah dengan Peraturan Pemerintah No 45 Tahun 1990 Tentang Izin Perkawinan dan Perceraian bagi PNS. Dalam peraturan pemerintah tersebut dinyatakan bahwa PNS pria yang akan beristri lebih dari seorang wajib memperoleh izin lebih dahulu dari pejabat dan PNS perempuan tidak di izinkan untuk menjadi istri kedua/ketiga/keempat. Dan permintaan izin bagi PNS pria terseut diajukan secara tertulis dengan mencantumkan alasan lengkap sebagai dasar permintaan izin untuk beristri lebih dari seorang. ${ }^{14}$

Aturan poligami yang mengikat PNS di Indonesia, dengan demikian bila dibandingkan dengan aturan poligami dalam undang-undang perkawinan tampak agak sedikit ketat dan sempit. Seperti telah dijelaskan diatas poligami diatur secara ketat oleh perundang-undangan Indonesia dan terlihat bahwa praktik poligami sangat dibatasi. Bila dibandingkan dengan hukum islam (fikih konvensional) dapat dilihat perbedaan keduanya. Dalam fikih seperti dalam halnya pendapat para ulama diharuskan adanya keadilan ketika seseorang hendak berpoligami. Meskipun begitu islam membuka peluang besar diperolehkannya poligami hingga batas empat orang istri. Berbeda dengan hal ini undang-undang perkawinan atau peraturan terkait justru memberikan batasan dengan syarat tertentu, sehingga poligami di Indonesia hanya sebatas pilihan bagi mereka yang tidak mampu menuju mahligai perkawinan ideal.

Meskipun demikian sejatinya praktik Poligami di Indonesia masih terbilang tinggi. Tingginya jumlah poligami tentu tidak dapat dilepaskan dari persepsi masyarakat Indonesia tentang lembaga poligami itu sendiri. seperti diketahui doktrin agama islam (fikih konvensional) yang notabene membolehkan poligami, telah

${ }^{14}$ Peraturan Pemerintah No 45 Tahun 1990 Tentang Izin Perkawinan dan Perceraian Bagi PNS 
dipegang masyarakat Indonesia selama berabad-abad, sehingga dalam beberapa masyarakat terjadi akulturasi yang begitu besar.

Dalam akulturasi inilah agama islam sangat mempengaruhi pandangan hidup dan sikap masyarakat Indonesia. Dalam hal ini pandangan hukum islam tradisional terhadap poligami sedikit banyak mempengaruhi persepsi masyarakat Indonesia. Penelitian yang dilakukan Center For Study Of Religion And Culture (CSRC) UIN Jakarta terhadap enam daerah di Indonesia menyebutkan bahwa mayoritas responden muslim (61\%) menyetujui adanya poligami, sedangkan yang tidak setuju hanya $31 \% .{ }^{15}$ Angka tersebut tentulah bukan angka yang kecil, apalagi dalam undangundang sendiri dijelaskan bahwa prinsip perkawinan di Indonesia adalah monogami relatif yang artinya memberikan peluang untuk terjadinya poligami dengan syarat tertentu. Meskipun tidak disebutkan presentasenya, menurut penelitian ini mayoritas responden yang setuju dengan poligami adalah responden laki-laki.

Persepsi ini pun sejatinya dapat dikatakan sebanding dengan praktik dan pengalaman responden bagi yang setuju dengan adanya poligami. Jadi bukan hanya diatas kertas. Menurut penelitian ini sebanyak 56\% menyatakan bahwa mereka mengalami baik secara langsung, orang tua atau orang-orang yangmereka kenal menjalani pernikahan poligami. Sementara jumlah yang tidak mengalami atau terkait dengan praktik ini hanya $40 \%$ dan selebihnya tidak tahu16. Namun angka yang ada diatas juga berbeda dengan hasil penelitian yang dilakukan oleh Dr. Ahmad Tholabi di Lebak. ${ }^{17}$ Meski dikenal dengan tradisional dan kuat islamnya, mayoritas responden justru tidak setuju dengan poligami (70,5\%). Tampaknya alasan yang bersifat doktriner (fikih konvensional) menjadi dasar argument atas persepsi dukungan terhadap poligami. Perlu diketahui dalam perkembangannya ada pemahaman terhadap islam tradisionaldan islam modern yang mana keduanya memiliki perbedaan pendapat.

Seperti yang dilansir Nasrudin Umar, poligami menjadi masalah yang serius

\footnotetext{
${ }^{15}$ Sukron Kamil \& Chaider S. Bamualim (ed). Syariah Islam \& HAM : Dampak Perda Syariah Terhadap Kebebasan Sipil, Hak-Hak Perempuan \& Non Muslim (CSRC UIN 2007).[169].

${ }^{16}$ ibid. [170].

${ }^{17}$ Ahmad Tholabi, Hukum Keluarga Indonesia (Sinar Grafika 2013).[23].
} 
dalam perkawinan. Dalam data Ditjen Bimas Islam, poligami menjadi penyumbang angka yang sangat besar terhadap perceraian, menjadi salah satu alasan perceraian adalah poligami. Sebanyak 813 perceraian pada 2004 disebabkan oleh poligami. Mengapa demikian, karena istri biasanya lebih memilih bercerai dari pada dijadikan istri tua. ${ }^{18}$ Untuk melihat praktik ini, sangat relevan jika kita kembali mengacu pada proses modernisasi masyarakat yang telah dijelaskan sebelumnya. Dalam masyarakat modern, dimana peran ekonomi perempuan semakin meningkat dan karier mereka pun semakin maju, sehingga ketergantungan ekonomi pun tidak lagi kuat, maka sangat mungkin perempuan memilih bercerai dari pada hidup dimadu. ${ }^{19}$ Dari sinilah dapat dilihat mengapa angka perceraian karena alasan poligami semakin tinggi dipengadilan. Dan jika melihat konteks masyarakat seperti ini, dapat dicatat bahwa hukum keluarga di Indonesia telah melakukan upaya perbaikan sistem hukum, termasuk didalamnya membatasi praktik poligami dan menjawab perubahan zaman yang semakin modern.

Ada beberapa faktor yang membuat masyarakat melakukan poligami secara illegal, diantara sebab yang dapat disebutkan adalah : (a) sulitnya proses perkawinan di KUA atau izin pengadilan di pengadilan agama, (b) sulitnya mendapatkan izin istri terdahulu. ${ }^{20}$ Bila diamati dari beberapa faktor diatas, perkawinan poligami illegal dilakukan oleh pasangan menikah tersebut justru memiliki unsur yang bertentangan dengan undang-undang perkawinan, seperti keharusan izin dari istri, prosedur di pengadilan dan KUA. Hanya faktor terakhir yang bersifat kultural, dimana masyarakat mengakuinya. Lalu bagaimana dengan sanksi yang telah ditetapkan dalam undang-undang perkawinan ? menurut penelitian M. Ja'far,di Pidie, Aceh hingga 1988 poligami illegal banyak dilakukan dan pada saat yang sama sanksi yang tertera dalam undang-undang perkawinan atau peraturan pelaksananya sama sekali tidak pernah diterapkan. ${ }^{21}$

\footnotetext{
${ }^{18}$ Essam Fauzy, "Understanding The Law : Egyptian Family \& Social Attitude (Result Of The Field Study) ”; Lynn Welcmann, “Women's Rights \& Islamic Family Law Perspectives On Reform ”. [51].

${ }^{19}$ M. Jaffar, 'Perkawinan Poligami Dalam Masyarakat Pidie' (1998).[33-54].

${ }^{20}$ ibid. [50-54].

${ }^{21}$ ibid.[35].
} 


\section{Hukum Perkawinan (Malaysia)}

Keenganan masyarakat untuk meninggalkan praktik poligami, pada daerahdaerah tertentu yang memiliki struktur adat yang masih berfungsi, justru menjadikan praktik poligami illegal banyak dilakukan. Sementara disisi yang lain, sanksi yang telah ditetapkan oleh undang-undang pun tidak kunjung datang dan diberlakukan. Dalam hal ini poligami sering dilakukan dan hingga kini poligami menjadi salah satu faktor tertinggi terjadinya perceraian di Indonesia.

Di Negara Malaysia sebagai Negara yang menganut sistem common law sangat mengatur secara keras terhadap larangan poligami ini bisa dilihat dari hukum perkawinan di Malaysia. Meskipun tidak semua kawasan dimalaysia menggunakan aturan yang sama, namun pada dasarnya tetap melihat aspek poligami sebagai sebuah tindakan negative. Berikut ini perbedaan antara hukum keluarga Indonesia dan Malaysia terkait poligami.

Indonesia:

1. Sistem hukum adalah CIVIL LAW (bekas Negara Jajahan Belanda);

2. Dominasi masyarakat muslim;

3. Dalam perundang-undangan perkawinan Indonesia No 1 Tahun 1974 pasal 3 adanya penegasan tentang prinsip perkawinan yang digunakan yaitu prinsip Monogami Relatif;

4. Terdapat sanksi pada UU Perkawinan No 1 Tahun 1974 dan peraturan pelaksana terhadap pelanggaran pelaksanaan poligami, hanya saja tidak diterapkan secara tegas (secara praktiknya masih belum dilaksanakan / tidak pernah diterapkan hanya tertulis);

5. Poligami bukanlah tindakan kriminal;

6. Menggunakan UU buatan asli Indonesia yang digunakan sama diseluruh daerah Indonesia serta digunakan oleh seluruh agama (unifikasi);

7. UU yang digunakan UU No 1 Tahun 1974 dengan Peraturan pelaksana PP No 9 Tahun 1975;

8. Terkait aturan poligami jelas "Eksplisit" menganut monogamy relative "Eksplisit" tetapi masih ditemukan kekurangan dalam pengaturannya. Selain itu hukum agama dan hukum Negara berjalan berdampingan.

Malaysia:

1. Sistem hukum adalah COMMON LAW (bekas Negara Jajahan Inggris);

2. Dominasi masyarakat muslim;

3. Dalam perundang-undangan Malaysia tidak ada penegasan tentang prinsip perkawinan yang digunakan;

4. Terdapat sanksi yang jelas dan tegas (baik pidana / denda) bagi yang melakukan 
pelanggaran terhadap pelaksanaan poligami;

5. Diancam sanksi pidana apabila melaksanakan tidak sesuai prosedur, sebab pada Negara common law poligami dianggap sebagai sebuah tindakan kriminal;

6. Masih menggunakan UU perkawinan peninggalan / buatan inggris dan belum memiliki UU perkawinan yang asli buatan Negara Malaysia;

7. Tiap Negara bagian di Malaysia memiliki UU domestik perkawinan sehingga itu sebabnya pengaturan poligami ditiap daerah di Malaysia berbeda-beda;

8. Adanya kebimbangan dalam penegakan aturan poligami di Malaysia antara hukum Negara dengan hukum agama (islam).

Sumber: Bahan Hukum Primer, diolah dari berbagai sumber, 2015.

Penjelasan hukum keluarga di Malaysia terkait poligami: berdasarkan undang-undang perkawinan Malaysia tentang boleh atau tidaknya seorang laki-laki melakukan poligami, ada 3 hal yang menjadi topic yang perlu dibicarakan:

(1) Syarat-syarat;

(2) Alasan-alasan pertimbangan boleh atau tidaknya melaksanakan poligami;

(3) Prosedur.

Dalam perundang-undang Malaysia tidak ada penegasan tentang prinsip perkawinan apakah "Monogami Mutlak" atau "Monogami Relatif" dan berbanding terbalik dengan prinsip perkawinan di Indonesia yang justru secara eksplisit menjelaskan prinsip yang digunakan adalah "Monogami Relatif” (pasal 3 UU No 1 Tahun 1974 Tentang Perkawinan). Suami yang melakukan poligami yang tidak sesuai dengan aturan perundang-undangan yang ditetapkan, secara umum dapat dikenai hukuman berupa hukuman denda maksimal seribu ringgit ${ }^{22}$ atau kurungan maksimal 6 bulan atau keduanya. Berikut dijelaskan Tentang Syarat, Alasan, Prosedur Pelaksanaan Poligami dalam Hukum Keluarga di Malaysia:

Syarat:

1. Poligami tanpa izin lebih dahulu dari pengadilan tidak boleh didaftarkan;

2. Poligami tanpa izin lebih dahulu dari pengadilan boleh didaftarkan dengan syarat terlebih dahulu membayar denda atau menjalani hukuman yang telah ditentukan. (**jumlah seribu ringgit jika dijadikan rupiah pada bulan Oktober 2002 akan menjadi Rp 2.250.000).

${ }^{22}$ Khoiruddin Nasution, Status Wanita di Asia Tenggara, (INIS 2002).[111-112]. 
Alasan Pertimbangan :

1. Alasan pertimbangan bagi pengadilan untuk memberi izin, atau tidak yaitu ada 3 pihak:
a. Pihak suami;
b. Pihak istri;
c. Pihak orang-orang yang terkait.

2. Adapun yang bersumber dari pihak istri adalah:
a. Karena kemandulan;
b. Keudzuran jasmani (fisikyang sudah menua);
c. Karena kondisi fisik yang tidak layak atau tidak mungkin melakukan hubungan seksual;
d. Sengaja tidak mau memulihkan hak-hak persetubuhan;
e. Istri gila.

3. Sedangkan pertimbangan dari pihak suami, yang sekaligus menjadi syarat boleh berpoligami atau tidak:
a. Suami mempunyai kemampuan untuk menanggung semua biaya istri- istri dan orang-orang yang akan menjadi tanggungannya kelak dengan perkawinan tersebut;
b. Suami berusaha berbuat adil diantara para istrinya.

4. Adanya pertimbangan dari pihak orang-orang terkait yang lebih tepat disebut orang yang terkena akibat dari poligami adalah:
a. Bahwa perkawinan tersebut tidak menjadikan istri-istri yang sudah dinikahi menjadi di mudharatkan;
b. Poligami tersebut tidak merendahkan langsung terhadap taraf hidup (martabat) orang-orang yang sebelumnya menjadi tanggungannya.

Prosedur:

1. Prosedur untuk berpoligami ada 3 langkah :

a. Suami mengajukan permohonan untuk mendapatkan izin dari hakim, bersama persetujuan atau izin dari istri / istri-istrinya.

b. Pemanggilan pemohon dan istri / istri-istrinya sekaligus pemeriksaan oleh pengadilan terhadap kebenaran pemohon (putusan pengadilan berupa penerimaan atau penolakan terhadap permohonan pemohon). 
Dari penjelasan diatas, dapat disimpulkan bahwa Malaysia adalah sebuah Negara yang berasaskan Negara islam. Undang-undangnya pun bersumber atau menggunakan hukum islam, meskipun ada sebagian sumber hukumnya yang mengadopsi atau bersumber dari produk hukum inggris (karena Negara bekas jajahan inggris $)^{23}$. Dalam masalah aturan hukum perdata Malaysia memberlakukan aturan hukum yang berbeda-beda, tidak semua penerapan hukum yang berlaku di Malaysia sama, akan tetapi bergantung atas hukum wilayah masing-masing khususnya masalah hukum perdata. (Sumber: bahan hukum primer, diolah dari berbagai sumber, 2015).

\section{Kesimpulan}

Adanya problematika pada pengaturan asas monogami dalam UU No 1 Tahun 1974 tentang perkawinan memperlihatkan kondisi saat ini. Problematika yang meliputi kekaburan norma pada beberapa pasal terkait asas monogami terutama syarat alternatif dan kumulatif untuk berpoligami, sehingga menimbulkan multitafsir dimasyarakat sebagai pelaksana dan penegak hukum dalam hal ini hakim (sebagai pengawas pelaksana apabila terjadi pelanggaran serta memeriksa dan memutus suatu perkara terkait poligami). Dalam hal interpretasi atau menafsirkan aturan pada pasal yang berdampak adanya ketidakpastian hukum terutama pada kaum wanita sebagai pihak yang disudutkan sehingga perlu adanya upaya perlindungan hukum.

\section{Daftar Bacaan}

\section{Buku}

A.Bakri Rahman \& Ahmad Sukardja, Hukum Perkawinan Menurut Islam, UndangUndang Perkawinan \& Hukum Perdata (Hidakarya Agung 1981).

Ahmad Tholabi, Hukum Keluarga Indonesia (Sinar Grafika 2013).

Amiur Nuruddin \& Azhari Akmal Tarigan, Hukum Perdata Islam Di Indonesia: Studi Kritis Perkembangan Hukum Islam Dari Fikih, UU No 1 Tahun 1974 (Prenada Media Group 2006).

23 Aafandia, 'Hukum Islam Di Negara Malaysia' (2015) <http://aafandia.wordpress. com/2009/05/20/hukum-islam-di-negara-malaysia $>$ accessed 7 November 2015. 
Haifah A. Jawaad, Otentisitas Hak-Hak Perempuan Dalam Islam.

Hazairi, Tinjauan Mengenai UU Perkawinan, UU No 1 Tahun 1974 (Tinta Mas 2006).

Hilman Hadikusuma, Hukum Perkawinan Indonesia Menurut Perundangan, Hukum Adat, Hukum Agama (Mandar Maju 2007).

Kartini, Surat-Surat Kepada Ny. Abendanon Mandiri \& Saminya (Djambatan 1989).

Khoiruddin Nasution, Status Wanita Di Asia Tenggara (INIS 2002). , Riba \& Poligami : Sebuah Studi Atas Pemikiran Muhammad Abduh (Pustaka Pelajar 1996).

Mufidah CH, Psikologi Keluarga Islam Berwawasan Gender.

Sukron Kamil \& CSB (ed), Syariah Islam \& HAM: Dampak Perda Syariah Terhadap Kebebasan Sipil, Hak-Hak Perempuan \& Non Muslim (CSRC UIN 2007).

Warkum Sumitro MAK dan IM, Konfigurasi Fiqih Poligini Kontemporer (Kritik Terhadap Paham Ortodoksi Perkawinan Poligini Di Indonesia)(UB Press 2009).

\section{Jurnal}

Ilvi Nur Diana, 'Wacana \& Gerakan Perempuan Islam Di Indonesia' E-Jurnal UIN Malang.

Khoirudin Nasution, 'Polygami In Indonesia Islamic Family Law' (2008) jilid 16 B jurnal syariah.

M. Jaffar, 'Perkawinan Poligami Dalam Masyarakat Pidie' (1998).

M. Yunan Yusuf, 'Karakteristik Tafsir Al-Qur'an Di Indonesia Abad Keduapuluh', Ulumul Qur'an III Vol 4 (1992).

\section{Laman}

Aafandia, 'Hukum Islam Di Negara Malaysia' (2015) <http://aafandia.wordpress. com/2009/05/20/hukum-islam-di-negara-malaysia $>$ accessed 7 November 2015.

HOW TO CITE: Avisena Aulia Anita, 'Perbandingan Pengaturan Asas Monogami Antara Negara Civil Law (Indonesia) dan Common Law (Malaysia)' (2018) Vol. 1 No. 1 Notaire. 
--Halaman ini sengaja dibiarkan kosong-- 